\title{
Nickel-Catalyzed Coupling of Arenesulfonates with Primary Alkylmagnesium Halides
}

\author{
Chul-Hee Cho, Myungchul Sun, and Kwangyong Park*
}

\author{
School of Chemical \& Materials Engineering, Chung-Ang University, Seoul 156-756, Korea. *E-mail: kypark@cau.ac.kr \\ Received June 13, 2005
}

\begin{abstract}
Neopentyl arenesulfonates reacted with primary alkylmagnesium halides in the presence of $\left(\mathrm{PPh}_{3}\right)_{2} \mathrm{NiCl}_{2}$ to produce the corresponding alkylarenes. The efficiency of this coupling reaction considerably depends on the nature of catalyst and solvent. Highest yield was obtained by using three equivalents of Grignard reagent to a mixture of $\left(\mathrm{PPh}_{3}\right)_{2} \mathrm{NiCl}_{2}$ and arenesulfonate in refluxing $\mathrm{Et}_{2} \mathrm{O}$. This reaction represents a novel method allowing the efficient and creative substitution of sulfur-containing groups in aromatic compounds. It also shows that the alkyloxysulfonyl group might be a suitable alternative to halides and triflate in some circumstances.
\end{abstract}

Key Words : Primary alkyl Grignard reagents, Arenesulfonates, Cross-coupling, Nickel catalyst

\section{Introduction}

Cross-coupling reaction of organometallic nucleophiles with organic electrophiles using transition metal catalysts is among the most useful processes for constructing carboncarbon bonds. ${ }^{1}$ The nickel- and palladium-catalyzed reactions of organoboronic acids, ${ }^{2}$ organostannanes, ${ }^{3}$ organozincs, ${ }^{4}$ alkenes and alkynes, ${ }^{5}$ and arylmagnesium halides ${ }^{6}$ are most popular in this family. The repertoire of these reactions has recently increased in the area of solid-phase parallel synthesis/combinatorial chemistry ${ }^{7}$ since $\operatorname{Pd}(0)$ mediated $\mathrm{C}-\mathrm{C}$ bond forming reactions were first explored on solid supports in the early 1990s. ${ }^{8}$ However, the satisfactory electrophilic components of these reactions have been limited to organic halides and triflates in most reports in spite of the enormous effort to diversify the leaving group of the electrophiles. ${ }^{9}$

We recently reported that the alkyloxysulfonyl moiety attached onto aromatic compounds could act as an excellent leaving group in the nickel-catalyzed reactions with aryl and primary alkyl Grignard reagents. ${ }^{10}$ Surprisingly, neopentyl arenesulfonates did not undergo the famous coupling reaction with arylmagnesium bromides via the displacement of the arenesulfonates under the standard reaction conditions. Moreover, alkyloxysulfonyl groups showed a good chemoselectivity by efficiently reacting with a nickel catalyst but not with palladium catalysts at all. Indeed, the stepwise palladium- and nickel-catalyzed reaction of bromobenzenesulfonates has been successfully demonstrated to be a promising and conceptually straightforward route for preparing unsymmetrical terphenyls. ${ }^{11}$ However, in previous reports, the alkyl nucleophilic substrates were restricted to methyl and neopentylmagnesium bromides, which do not possess $\beta$-hydrogen to the metal.

While aryl nucleophiles have been thoroughly investigated and applied in most transition metal-catalyzed couplings, the use of unactivated alkyl nucleophiles has been less explored. ${ }^{12}$ Only a limited number of methyl and primary alkyl Grignard reagents have been reported to

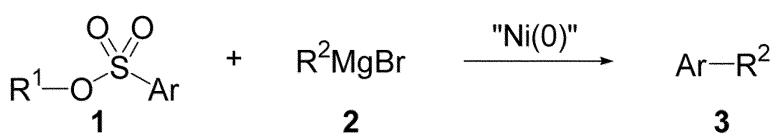

$$
\begin{aligned}
& \mathrm{R}^{1} \text { : 2,2-dimethyl-3-phenyl-1-propyl } \\
& \mathrm{R}^{2} \text { : ethyl, } n \text {-butyl, } n \text {-pentyl } \\
& \mathrm{Ar} \text { : toluene, naphthalene, biphenyls }
\end{aligned}
$$

Scheme 1

undergo the coupling reactions with aryl or vinyl halides in moderate yields. ${ }^{13}$ The reactions of secondary or tertiary alkylmagnesium halides have resulted in disappointing yields due to the isomerization of the alkyl groups. ${ }^{14}$ Therefore, the development of a general coupling procedure utilizing unactivated $s p^{3}$ nucleophiles represents an interesting challenge in the field of organic synthesis.

In a program directed at the development of a crosscoupling reaction utilizing unactivated alkyl nucleophiles, we recently observed that arenesulfonates readily undergo nickel-catalyzed reactions with primary alkylmagnesium halides to produce the corresponding alkylarenes under the specific reaction conditions (Scheme 1). It was noteworthy that the reaction efficiency significantly depends on the nature of catalyst and solvent. The preliminary results of those coupling reactions between alkyloxysulfonylarenes and alkylmagnesium bromides are presented and discussed below.

\section{Results and Discussion}

Alkyl arenesulfonates $\mathbf{1 a}$ and $\mathbf{1 b}$ were prepared by the reactions between 2,2-dimethyl-3-phenyl-1-propanol and arenesulfonyl chlorides. ${ }^{9}$ Biphenylsulfonates 1c-1f were prepared by the palladium-catalyzed coupling reactions of 2,2-dimethyl-3-phenyl-1-propyl 4-bromobenzenesulfonate with the corresponding arylboronic acids. ${ }^{11,15}$ Neopentyl moiety was selected as the alkyl groups for the sulfonates in order to avoid the competitive substitution and elimination 
Table 1. Effect of Varying Reaction Conditions on the Coupling of $\mathbf{1 b}$ with $\mathbf{2 a}$

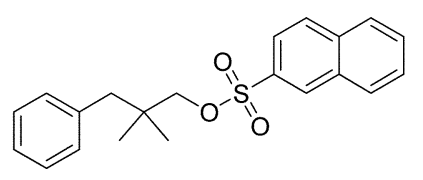

$1 b$

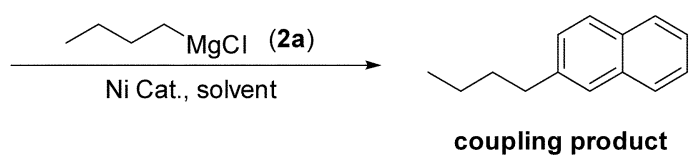

(A)

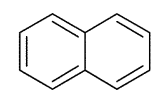

reduction product

(B)

\begin{tabular}{|c|c|c|c|c|c|c|}
\hline \multirow{2}{*}{ entry } & \multirow{2}{*}{ catalyst } & \multirow{2}{*}{$\mathbf{2 a}$ (equiv) } & \multirow{2}{*}{ solvent } & \multirow{2}{*}{ temperature } & \multicolumn{2}{|c|}{ yield $(\%)^{a}$} \\
\hline & & & & & $\mathbf{A}$ & B \\
\hline 1 & dppeNiCl 2 & 3 & THF & reflux & 16 & 53 \\
\hline 2 & $\mathrm{dpppNiCl}_{2}$ & 3 & $\mathrm{THF}$ & reflux & 16 & 53 \\
\hline 3 & $\mathrm{dppfNiCl}{ }_{2}$ & 3 & $\mathrm{THF}$ & reflux & 17 & 47 \\
\hline 4 & $\left(\mathrm{PPh}_{3}\right)_{2} \mathrm{NiCl}_{2}$ & 3 & $\mathrm{THF}$ & reflux & 46 & 27 \\
\hline 6 & $\mathrm{dppfNiCl}_{2}$ & 3 & $\mathrm{Et}_{2} \mathrm{O}$ & reflux & 15 & 47 \\
\hline 7 & $\left(\mathrm{PPh}_{3}\right)_{2} \mathrm{NiCl}_{2}$ & 3 & $\mathrm{Et}_{2} \mathrm{O}$ & reflux & 85 & 11 \\
\hline 8 & $(\operatorname{acac})_{2} \mathrm{Ni}$ & 3 & $\mathrm{Et}_{2} \mathrm{O}$ & reflux & 11 & 52 \\
\hline 9 & $\left(\mathrm{PPh}_{3}\right)_{2} \mathrm{NiCl}_{2}$ & 3 & DME & reflux & 53 & 38 \\
\hline 10 & $\left(\mathrm{PPh}_{3}\right)_{2} \mathrm{NiCl}_{2}$ & 3 & $\mathrm{Et}_{2} \mathrm{O}$ & $\mathrm{rt}$ & 69 & 14 \\
\hline 11 & $\left(\mathrm{PPh}_{3}\right)_{2} \mathrm{NiCl}_{2}$ & $3+2$ & $\mathrm{Et}_{2} \mathrm{O}$ & reflux & 85 & 12 \\
\hline
\end{tabular}

${ }^{a}$ All yields were determined by GC analyses using biphenyl as an internal standard.

of arenesulfonate anions in the following reactions with alkyl nucleophiles. The displacement of the arenesulfonates and neopentyloxysulfonyl groups was not observed under the standard Suzuki-Miyaura reaction conditions.

The cross-coupling reaction between 2-naphthalenesulfonate (1b) and $n$-butylmagnesium bromide (2a) was investigated first in order to uncover optimum reaction conditions (Table 1). The reactions performed in THF as the solvent generated more reduction product $\mathbf{B}$ than coupling product $\mathbf{A}$ in the presence of most nickel catalysts (entries 1-3). Only bis(triphenylphosphine)nickel dichloride produced the desired coupling product as the major product, although the efficiency was not good enough (entry 4). This nickel catalyst showed the great selectivity and conversion for $\mathbf{A}$ in refluxing diethyl ether (entry 7), while other catalysts still produced $\mathbf{B}$ more (entries 5, 6, and 8). DME was not a good solvent for this catalyst especially in terms of the selectivity (entry 9). This is interesting because THF is the best solvent for the reactions of aryl and methyl Grignard reagents. ${ }^{9,11}$ The reaction requires an elevated temperature to overcome the relatively low reactivity of $\mathbf{1 b}$. Reaction conducted in $\mathrm{Et}_{2} \mathrm{O}$ at room temperature could not be completed within $24 \mathrm{~h}$ (entry 10), while the reactions performed in refluxing $\mathrm{Et}_{2} \mathrm{O}$ were finished within $12 \mathrm{~h}$. Three equivalents of Grignard reagents are sufficient for the complete reaction. More addition of 2a did not improve the reaction efficiency (entry 11). In summary, the optimization studies demonstrate that the highest yield is obtained by using three equivalents of $\mathbf{2 a}$ to a mixture of $\left(\mathrm{PPh}_{3}\right)_{2} \mathrm{NiCl}_{2}$ and $\mathbf{1 b}$ in refluxing $\mathrm{Et}_{2} \mathrm{O}$.

The results of cross-coupling reactions between the various arenesulfonates $\mathbf{1}$ and the primary alkylmagnesium bromides 2, performed in the presence of $5 \mathrm{~mol} \%$ of $\left(\mathrm{PPh}_{3}\right)_{2} \mathrm{NiCl}_{2}$ in refluxing $\mathrm{Et}_{2} \mathrm{O}$, are summarized in Table 2.
The arenesulfonates underwent the reaction with $\mathbf{2 a}$ to give the corresponding $n$-butylarenes, $\mathbf{3 a - 3 f}$, in good yields within $12 \mathrm{~h}$ (entries 1-6). Most of the reactions showed the good selectivity for the coupling products $\mathbf{A}$ under the standard reaction conditions. The reaction of benzenesulfonate 1a required more time than those of naphthalenesulfonate (1b) and biphenylsulfonates (1c-1f) as the faster reaction of the more conjugated arenesulfonates has been consistently observed in these reactions. ${ }^{9-11}$ The isolated yield of 4-n-butyltoluene (3a) was relatively low due to its volatility, although its GC yield was reasonable. Methoxybiphenylsulfonate 1f also gave comparable yields without undergoing any secondary cross-coupling reaction with excess Grignard reagents via the cleavage of the carbonoxygen bonds (entries 6 and 7). ${ }^{16}$ Ethyl- (2b) and $n$-pentylmagnesium bromides (2c) underwent the cross-coupling reactions well enough to produce the corresponding biphenyls $\mathbf{3 g}-\mathbf{3 i}$ in good yields (entries 7-9).

\section{Conclusions}

In summary, neopentyl arenesulfonates were reacted with primary alkylmagnesium halides in the presence of $\left(\mathrm{PPh}_{3}\right)_{2}-$ $\mathrm{NiCl}_{2}$ to produce the corresponding alkylarenes. To our knowledge, the study reported above is the first general exploration of transition metal-catalyzed cross-coupling reactions of alkyloxysulfonyl arenes with typical primary alkyl nucleophiles. The application of optimum combination of the reaction conditions was very important for the successful result, because the efficiency of this coupling reaction considerably depends on the nature of catalyst and solvent. This reaction represents a novel method allowing the efficient and creative substitution of sulfur-containing groups in aromatic compounds. It also shows that the 
Table 2. Cross-coupling of sulfonates $\mathbf{1}$ with alkylmagnesium halides $\mathbf{2}^{a}$

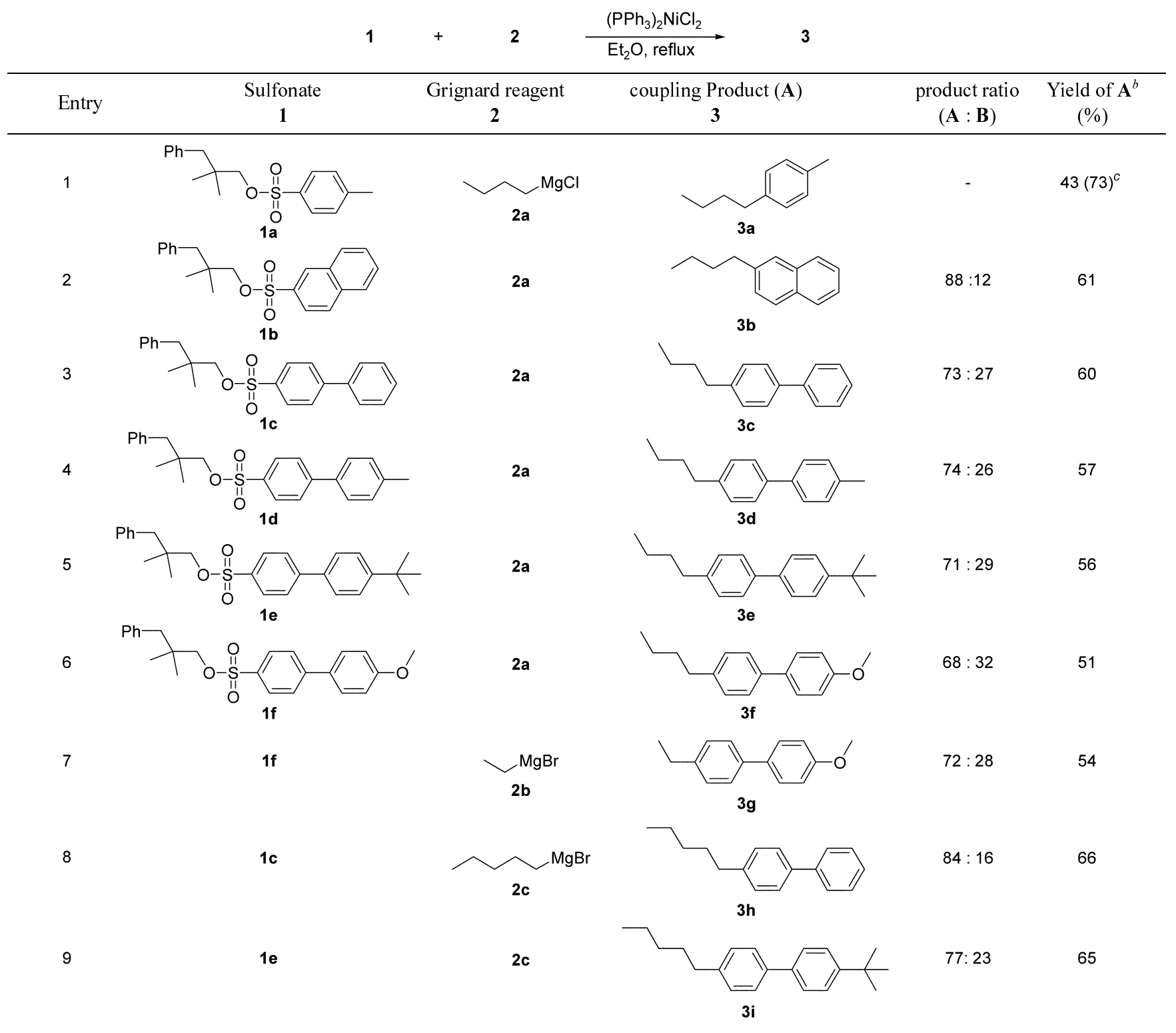

${ }^{a}$ Reactions of sulfonates $1(0.200 \mathrm{mmol})$ with $2(0.600 \mathrm{mmol})$ were carried out at the refluxing temperature of $\mathrm{Et}_{2} \mathrm{O}(6.0 \mathrm{~mL})$ by using $\left(\mathrm{PPh}_{3}\right)_{2} \mathrm{NiCl}_{2}$ $(0.010 \mathrm{mmol}){ }^{b}$ Isolated yields of the coupling product, A, based on $1{ }^{c}$ The value in parenthesis indicate GC yield based on 1 .

alkyloxysulfonyl group might be a suitable alternative to halides and triflate in some circumstances, especially when a chemoselective leaving group, which is inert toward palladium catalysts but reactive with nickel catalysts, is desirable.

\section{Experimental Section}

${ }^{1} \mathrm{H}$ NMR (300 or $500 \mathrm{MHz}$ ) and ${ }^{13} \mathrm{C}$ NMR (75 or 125 $\mathrm{MHz}$ ) were registered in $\mathrm{CDCl}_{3}$ or acetone- $d_{6}$ as solvent and tetramethylsilane (TMS) as internal standard. Chemical shifts are reported in $\delta$ units (ppm) by assigning TMS resonance in the ${ }^{1} \mathrm{H}$ spectrum as $0.00 \mathrm{ppm}$ and $\mathrm{CDCl}_{3}$ resonance in the ${ }^{13} \mathrm{C}$ spectrum as $77.2 \mathrm{ppm}$. All coupling constants $(J)$ are reported in hertz $(\mathrm{Hz})$. Column chromatog- raphy was performed on silica gel 60, 70-230 mesh. Analytical thin-layer chromatography (TLC) was performed using Merck Kieselgel $60 \mathrm{~F}_{254}$ precoated plates $(0.25 \mathrm{~mm})$ with a fluorescent indicator and visualized with UV light (254 and $365 \mathrm{~nm}$ ) or by iodine vapor staining. GC analysis was performed on a bonded 5\% phenylpolysiloxane BPX 5 capillary column (SGE, $30 \mathrm{~m}, 0.32 \mathrm{~mm}$ i.d.). Electron impact (EI, $70 \mathrm{eV}$ ) was used as the ionization method for the mass spectrometry. Melting points were obtained using a Barnstead/Thermolyne MEL-TEMP apparatus and are uncorrected. Solvents were distilled from an appropriate drying agent prior to use: THF and DME from sodiumbenzophenone ketyl, and $\mathrm{Et}_{2} \mathrm{O}$ from calcium hydride. $\mathrm{DppfNiCl}_{2}$ was prepared according to a literature procedure. ${ }^{17} \mathrm{DppeNiCl}_{2}, \mathrm{dpppNiCl}_{2},\left(\mathrm{PPh}_{3}\right)_{2} \mathrm{NiCl}_{2}$ and $(\mathrm{acac})_{2} \mathrm{Ni}$ 
were purchased. $n$-Butyl- 2a (2.0 M, THF), $n$-ethyl- $2 \mathbf{b}(1.0$ $\mathrm{M}, \mathrm{THF})$, and $n$-pentylmagnesium bromide $2 \mathrm{c}\left(2.0 \mathrm{M}, \mathrm{Et}_{2} \mathrm{O}\right)$ were also purchased, and used as received.

General Procedure for Cross-Coupling Reaction. To a stirred solution of sulfonates $1(0.200 \mathrm{mmol})$ and $\left(\mathrm{PPh}_{3}\right)_{2}$ $\mathrm{NiCl}_{2}(0.010 \mathrm{mmol})$ in dry $\mathrm{Et}_{2} \mathrm{O}(6 \mathrm{~mL})$ was added primary alkyl Grignard reagents $2(0.600 \mathrm{mmol})$ at room temperature under Ar atmosphere. The resulting mixture was heated at reflux for ca. $12 \mathrm{~h}$. The mixture was then allowed to cool to room temperature, diluted with $\mathrm{Et}_{2} \mathrm{O}(30 \mathrm{~mL})$, and quenched by the addition of a $1 \% \mathrm{HCl}(20 \mathrm{~mL})$. The organic layer was washed with water $(3 \times 20 \mathrm{~mL})$ and saturated brine $(20 \mathrm{~mL})$, dried over $\mathrm{MgSO}_{4}$, filtered, and concentrated under vacuo. The crude product was purified by an appropriate chromatography to give pure compound $\mathbf{3}$.

1-Butyl-4-methylbenzene (3a) was prepared by the reaction of $\mathbf{1 a}(63.7 \mathrm{mg}, 0.200 \mathrm{mmol})$ with $\mathbf{2 a}(0.300 \mathrm{~mL}$, $0.600 \mathrm{mmol})$ in the presence of $\left(\mathrm{PPh}_{3}\right)_{2} \mathrm{NiCl}_{2}$. The crude compound was purified by silica gel chromatography $\left(\mathrm{Et}_{2} \mathrm{O}\right.$ : $n$-hexane $=1: 20)$ to give $\mathbf{3 a}(38.4 \mathrm{mg}, 43 \%)$ as a colorless oil: TLC $R_{f} 0.61\left(\mathrm{Et}_{2} \mathrm{O}: n\right.$-hexane $\left.=1: 4\right) ;{ }^{1} \mathrm{H}$ NMR $(300$ $\left.\mathrm{MHz}, \mathrm{CDCl}_{3}\right) \delta 0.92(\mathrm{t}, J=7.3 \mathrm{~Hz}, 3 \mathrm{H}), 1.32-1.37(\mathrm{~m}, 2 \mathrm{H})$, $1.54-1.60(\mathrm{~m}, 2 \mathrm{H}), 2.31(\mathrm{~s}, 3 \mathrm{H}), 2.56(\mathrm{t}, J=7.7 \mathrm{~Hz}, 2 \mathrm{H})$, $7.07(\mathrm{~s}, 4 \mathrm{H}) ;{ }^{13} \mathrm{C} \mathrm{NMR}\left(75 \mathrm{MHz}, \mathrm{CDCl}_{3}\right) \delta 14.0,21.0,22.5$, 33.9, 35.4, $128.6(\times 2), 129.2(\times 2), 135.1,140.1$; HRMS (EI, $70 \mathrm{eV}$ ) calcd for $\mathrm{C}_{11} \mathrm{H}_{16}\left(\mathrm{M}^{+}\right), 148.1252$, found 148.1254 .

2-Butylnaphthalene (3b) was prepared by the reaction of 1 b $(70.9 \mathrm{mg}, 0.200 \mathrm{mmol})$ with $2 \mathbf{a}(0.300 \mathrm{~mL}, 0.600 \mathrm{mmol})$ in the presence of $\left(\mathrm{PPh}_{3}\right)_{2} \mathrm{NiCl}_{2}$. The crude compound was purified by preparative HPLC $\left(\mathrm{CH}_{3} \mathrm{CN}\right)$ to afford $\mathbf{3 b}(67.6$ $\mathrm{mg}, 61 \%)$ as a colorless oil: TLC $R_{f} 0.61\left(\mathrm{Et}_{2} \mathrm{O}: n\right.$-hexane $=$ $1: 4) ;{ }^{1} \mathrm{H}$ NMR $\left(300 \mathrm{MHz}, \mathrm{CDCl}_{3}\right) \delta 0.95(\mathrm{t}, J=7.31 \mathrm{~Hz}$, $3 \mathrm{H}), 1.31-1.46(\mathrm{~m}, 2 \mathrm{H}), 1.63-1.74(\mathrm{~m}, 2 \mathrm{H}), 2.77(\mathrm{t}, J=$ $7.64 \mathrm{~Hz}, 2 \mathrm{H}), 7.30-7.47(\mathrm{~m}, 3 \mathrm{H}), 7.61(\mathrm{~s}, 1 \mathrm{H}), 7.73-7.82$ $(\mathrm{m}, 3 \mathrm{H}) ;{ }^{13} \mathrm{C}$ NMR $\left(75 \mathrm{MHz}, \mathrm{CDCl}_{3}\right) \delta 14.1,22.5,33.6$, $35.9,125.2,126.1,126.6,127.7,127.7,127.9,128.0,132.2$, 134.0, 140.7; HRMS (EI, $70 \mathrm{eV}$ ) calcd for $\mathrm{C}_{14} \mathrm{H}_{16}\left(\mathrm{M}^{+}\right)$, 184.1252, found 184.1304 .

4-n-Butylbiphenyl (3c) was prepared by the reaction of 1c $(76.1 \mathrm{mg}, 0.200 \mathrm{mmol})$ with $2 \mathrm{a}(0.300 \mathrm{~mL}, 0.600 \mathrm{mmol})$ in the presence of $\left(\mathrm{PPh}_{3}\right)_{2} \mathrm{NiCl}_{2}$. The crude compound was purified by preparative HPLC $\left(\mathrm{CH}_{3} \mathrm{CN}\right)$ to afford 3c $(75.5$ $\mathrm{mg}, 60 \%$ ) as a colorless oil. ${ }^{18}$

4-n-Butyl-4'-methylbiphenyl (3d) was prepared by the reaction of $\mathbf{1 d}(78.9 \mathrm{mg}, 0.200 \mathrm{mmol})$ with $2 \mathbf{a}(0.300 \mathrm{~mL}$, $0.600 \mathrm{mmol})$ in the presence of $\left(\mathrm{PPh}_{3}\right)_{2} \mathrm{NiCl}_{2}$. The crude compound was purified by preparative $\mathrm{HPLC}\left(\mathrm{CH}_{3} \mathrm{CN}\right)$ to afford $3 d(77.3 \mathrm{mg}, 57 \%)$ as a white solid. ${ }^{18}$

4-Butyl-4'-tert-butylbiphenyl (3e) was prepared by the reaction of 1 e $(87.3 \mathrm{mg}, 0.200 \mathrm{mmol})$ with $2 \mathbf{2 a}(0.300 \mathrm{~mL}$, $0.600 \mathrm{mmol})$ in the presence of $\left(\mathrm{PPh}_{3}\right)_{2} \mathrm{NiCl}_{2}$. The crude compound was purified by preparative $\mathrm{HPLC}\left(\mathrm{CH}_{3} \mathrm{CN}\right)$ to afford $3 \mathbf{e}(89.5 \mathrm{mg}, 56 \%)$ as a white solid. ${ }^{19}$

4-n-Butyl-4'-methoxybiphenyl (3f) was prepared by the reaction of $\mathbf{1 f}(82.1 \mathrm{mg}, 0.200 \mathrm{mmol})$ with $2 \mathbf{a}(0.300 \mathrm{~mL}$, $0.600 \mathrm{mmol})$ in the presence of $\left(\mathrm{PPh}_{3}\right)_{2} \mathrm{NiCl}_{2}$. The crude compound was purified by preparative $\mathrm{HPLC}\left(\mathrm{CH}_{3} \mathrm{CN}\right)$ to give $3 f(73.3 \mathrm{mg}, 51 \%)$ as a white solid: TLC $R_{f} 0.51\left(\mathrm{Et}_{2} \mathrm{O}\right.$ : $n$-hexane $=1: 4) ; \mathrm{mp} 69-70{ }^{\circ} \mathrm{C}$ (uncorrected); ${ }^{1} \mathrm{H}$ NMR (300 MHz, $\left.\mathrm{CDCl}_{3}\right) \delta 0.94(\mathrm{t}, J=7.30 \mathrm{~Hz}, 3 \mathrm{H}), 1.28-1.43$ (m, 2H), 1.57-1.70 (m, 2H), $2.64(\mathrm{t}, J=7.81 \mathrm{~Hz}, 2 \mathrm{H}), 3.82$ (s, 3H), 6.97 (d, $J=8.70 \mathrm{~Hz}, 2 \mathrm{H}), 7.23$ (d, $J=8.40 \mathrm{~Hz}, 2 \mathrm{H})$, $7.45-7.53(\mathrm{~m}, 4 \mathrm{H}) ;{ }^{13} \mathrm{C} \mathrm{NMR}\left(75 \mathrm{MHz}, \mathrm{CDCl}_{3}\right) \delta 14.0$, $22.5,33.8,35.4,55.5,114.4(\times 2), 126.8(\times 2), 128.2(\times 2)$, 129.1 (×2), 134.1, 138.4, 141.7, 159.2; HRMS (EI, $70 \mathrm{eV})$ calcd for $\mathrm{C}_{17} \mathrm{H}_{20} \mathrm{O}\left(\mathrm{M}^{+}\right), 240.1514$, found 240.1532 .

4-Ethyl-4'-methoxybiphenyl (3g) was prepared by the reaction of $\mathbf{1 f}(82.1 \mathrm{mg}, 0.200 \mathrm{mmol})$ with $\mathbf{2 b}(0.600 \mathrm{~mL}$, $0.600 \mathrm{mmol})$ in the presence of $\left(\mathrm{PPh}_{3}\right)_{2} \mathrm{NiCl}_{2}$. The crude compound was purified by preparative $\mathrm{HPLC}\left(\mathrm{CH}_{3} \mathrm{CN}\right)$ to give $3 \mathbf{g}(68.7 \mathrm{mg}, 54 \%)$ as a white solid. ${ }^{20}$

4-Pentylbiphenyl (3h) was prepared by the reaction of $\mathbf{1 c}$ (76.1 $\mathrm{mg}, 0.20 \mathrm{mmol})$ with $2 \mathrm{c}(0.300 \mathrm{~mL}, 0.600 \mathrm{mmol})$ in the presence of $\left(\mathrm{PPh}_{3}\right)_{2} \mathrm{NiCl}_{2}$. The crude compound was purified by preparative HPLC $\left(\mathrm{CH}_{3} \mathrm{CN}\right)$ to give $\mathbf{3 h}(89.2 \mathrm{mg}$, $66 \%)$ as a pale yellow oil: TLC $R_{f} 0.64\left(\mathrm{Et}_{2} \mathrm{O}: n\right.$-hexane $=1$ : 4); ${ }^{1} \mathrm{H}$ NMR $\left(300 \mathrm{MHz}, \mathrm{CDCl}_{3}\right) \delta 0.90(\mathrm{t}, J=6.72 \mathrm{~Hz}, 3 \mathrm{H})$, $1.27-1.43(\mathrm{~m}, 4 \mathrm{H}), 1.56-1.73(\mathrm{~m}, 2 \mathrm{H}), 2.64(\mathrm{t}, J=7.72 \mathrm{~Hz}$, $2 \mathrm{H}), 7.24(\mathrm{~d}, J=8.56 \mathrm{~Hz}, 2 \mathrm{H}), 7.27-7.35(\mathrm{~m}, 1 \mathrm{H}), 7.42(\mathrm{t}, J$ $=7.22,7.72 \mathrm{~Hz}, 2 \mathrm{H}), 7.51(\mathrm{~d}, J=8.39 \mathrm{~Hz}, 2 \mathrm{H}), 7.55-7.61$ $(\mathrm{m}, 2 \mathrm{H}) ;{ }^{13} \mathrm{C} \mathrm{NMR}\left(75 \mathrm{MHz}, \mathrm{CDCl}_{3}\right) \delta 14.1,22.7,31.3$, $31.7,35.7,127.2,127.3(\times 2), 127.3(\times 2), 129.0(\times 2), 129.1$ $(\times 2), 138.8,141.5,142.4$; HRMS (EI, $70 \mathrm{eV}$ ) calcd for $\mathrm{C}_{17} \mathrm{H}_{20}\left(\mathrm{M}^{+}\right), 224.1565$, found 224.1604.

4-Pentyl-4'-tert-butylbiphenyl (3i) was prepared by the reaction of 1 e $(87.3 \mathrm{mg}, 0.200 \mathrm{mmol})$ with $2 \mathrm{c}(0.300 \mathrm{~mL}$, $0.600 \mathrm{mmol})$ in the presence of $\left(\mathrm{PPh}_{3}\right)_{2} \mathrm{NiCl}_{2}$. The crude compound was purified by preparative $\mathrm{HPLC}\left(\mathrm{CH}_{3} \mathrm{CN}\right)$ to give $3 \mathbf{i}(110 \mathrm{mg}, 65 \%)$ as a white solid: TLC $R_{f} 0.65\left(\mathrm{Et}_{2} \mathrm{O}\right.$ : $n$-hexane $=1: 4) ; \mathrm{mp} 56-57{ }^{\circ} \mathrm{C}$ (uncorrected); ${ }^{1} \mathrm{H} \mathrm{NMR}$ $\left(300 \mathrm{MHz}, \mathrm{CDCl}_{3}\right) \delta 0.90(\mathrm{t}, J=6.63 \mathrm{~Hz}, 3 \mathrm{H}), 1.36(\mathrm{~s}, 9 \mathrm{H})$, $1.25-1.42(\mathrm{~m}, 4 \mathrm{H}), 1.56-1.72(\mathrm{~m}, 2 \mathrm{H}), 2.63(\mathrm{t}, J=7.81 \mathrm{~Hz}$, $2 \mathrm{H}), 7.23(\mathrm{~d}, J=8.22 \mathrm{~Hz}, 2 \mathrm{H}), 7.40-7.55(\mathrm{~m}, 6 \mathrm{H}) ;{ }^{13} \mathrm{C}$ NMR $\left(75 \mathrm{MHz}, \mathrm{CDCl}_{3}\right) \delta 14.1,22.7,31.3,31.5(\times 3), 31.7$, 34.6, 35.7, $125.9(\times 2), 126.9(\times 2), 127.1(\times 2), 129.0(\times 2)$, 138.6, 138.7, 142.1, 150.2; HRMS (EI, $70 \mathrm{eV}$ ) calcd for $\mathrm{C}_{21} \mathrm{H}_{28}\left(\mathrm{M}^{+}\right)$, 280.2191, found 280.2182.

Acknowledgement. This Research was supported by the Creative Initiative Research Program of Chung-Ang University in 2004.

\section{References}

1. (a) Handbook of Organopalladium Chemistry for Organic Synthesis; Negishi, E.; de Meijere, A.; Bäckvall, J. E.; Cacchi, S.; Hayashi, T.; Ito, Y.; Kosugi, M.; Murahashi, S. I.; Oshima, K.; Yamamoto, Y., Eds.; Wiley-Interscience: New York, 2002. (b) Hassan, J.; Sevignon, M.; Gozzi, C.; Schulz, E.; Lemaire, M. Chem. Rev. 2002, 102, 1359. (c) Littke, A. F.; Fu, G. C. Angew. Chem. Int. Ed. 2002, 41, 4176. (d) Stanforth, S. P. Tetrahedron 1998, 54, 263.

2. (a) Kotha, S.; Lahiri, K.; Kashinath, D. Tetrahedron 2002, 58, 9633. (b) Suzuki, A. J. Organomet. Chem. 1999, 576, 147. (c) 
Miyaura, N.; Suzuki, A. Chem. Rev. 1995, 95, 2457.

3. (a) Farina, V.; Krishnamurthy, V.; Scott, W. J. The Stille Reaction; John Wiley \& Sons: New York, 1998. (b) Farina, V.; Krishnamurthy, V.; Scott, W. J. Org. React. 1997, 50, 1. (c) Stille, J. K. Angew. Chem., Int. Ed. Engl. 1986, 25, 508.

4. (a) Negishi, E. In Organozinc Reagents: A Practical Approach; Knochel, P.; Jones, P., Eds.; Oxford University Press: Oxford, 1999; Chapter 11, pp 213-243. (b) Knochel, P.; Almena Perea, J. J.; Jones, P. Tetrahedron 1998, 54, 8275. (c) Erdik, E. In Organozinc Reagents in Organic Synthesis; CRC Press: Boca Raton, 1996; Chapter 7, pp 271-343. (d) Negishi, E. Acc. Chem. Res. 1982, 15, 340 .

5. (a) Whitcombe, N. J.; Hii, K. K.; Gibson, S. E. Tetrahedron 2001, 57, 7449. (b) Biffis, A.; Zecca, M.; Basato, M. J. Mol. Catal. AChem. 2001, 173, 249. (c) Shibasaki, M.; Boden, C. D. J.; Kojima, A. Tetrahedron 1997, 53, 7371.

6. (a) Karlsträm, A.; Sofia, E.; Itami, K.; Bäckvall, J.-E. J. Org. Chem. 1999, 64, 1745. (b) Busacca, C. A.; Eriksson, M. C.; Fiaschi, R. Tetrahedron Lett. 1999, 40, 3101. (c) Miller, J. A.; Farrell, R. P. Tetrahedron Lett. 1998, 39, 7275. (d) Tamao, K.; Kumada, M. In The Chemistry of the Metal-Carbon Bond; Hartley, F. R. Ed.; Wiley: New York, 1987; Vol. 4, p 820. (e) Kumada, M. Pure Appl. Chem. 1980, 52, 669. (f) Tamao, K.; Sumitani, K.; Kiso, Y.; Zembayashi, M.; Fujioka, A.; Kodama, S.; Nakajima, I.; Minato, A.; Kumada, M. Bull. Chem. Soc. Jpn. 1976, 49, 1958

7. (a) Bräse, S.; Kirchhoff, J. K.; Köbberling, J. Tetrahedron 2003, 59, 885. (b) Sammelson, R. E.; Kurth, M. J. Chem. Rev. 2001, 101, 137. (c) Franzén, R. Can. J. Chem. 2000, 78, 957. (d) Lorsbach, B. A.; Kurth, M. J. Chem. Rev. 1999, 99, 1549. (e) Andres, C. J.; Whitehouse, D. L.; Deshpande, M. S. Curr. Opin. Chem. Biol. 1998, 2, 353.

8. (a) Deshpande, M. S. Tetrahedron Lett. 1994, 35, 5613. (b) Yu, K.-L.; Deshpande, M. S.; Vyas, D. M. Tetrahedron Lett. 1994, 35, 8919. (c) Frenette, R.; Friesen, R. W. Tetrahedron Lett. 1994, 35, 9177

9. For recent reports for the $\mathrm{Pd}-$ and Ni-catalyzed coupling of nonconventional organic electrophiles, see: (a) Blakey, S. B.; MacMillan, D. W. C. J. Am. Chem. Soc. 2003, 125, 6046. (b)
Inoue, A.; Shinokubo, H.; Oshima, K. J. Am. Chem. Soc. 2003, 125, 1484. (c) Mayers, A. G.; Tanaka, D.; Mannion, K. R. J. Am. Chem. Soc. 2002, 124, 11250. (d) Stephan, M. S.; Taunissen, A. J. J. M.; Verzijl, G. K. M.; de Vries, J. G. Angew. Chem. Int. Ed. 1998, 37, 662. (e) Gooßen, L. J.; Paetzold, J. Angew. Chem. Int Ed. 2002, 41, 1237.

10. (a) Cho, C.-H.; Sun, M.; Seo, Y.-S.; Kim, C.-B.; Park, K. J. Org. Chem. 2005, 70, 1482. (b) Cho, C.-H.; Yun, H.-S.; Park, K. J. Org Chem. 2003, 68, 3017.

11. Cho, C.-H.; Kim, I.-S.; Park, K. Tetrahedron 2004, 60, 4589.

12. (a) Jensen, A. E.; Knochel, P. J. Org. Chem. 2002, 67, 79. (b) Kirchhoff, J. H.; Dai, C.; Fu, G. C. Angew. Chem. Int. Ed. 2002, 41, 1945. (c) Dübner, F.; Knochel, P. Tetrahedron Lett. 2000, 41, 9233. (d) Littke, A. F.; Fu, G. C. Angew. Chem. Int. Ed. 1999, 38, 2411.

13. (a) Terao, J.; Watanabe, H.; Ikumi, A.; Kuniyasu, H.; Kambe, N. J. Am. Chem. Soc. 2002, 124, 4222. (b) Seo, Y.-S.; Yun, H.-S.; Park, K. Bull. Korean Chem. Soc. 1999, 20, 1345. (c) Kumada, M.; Tamao, K.; Sumitani, K. Org. Synth. Coll. Vol. 1988, 6, 407. (d) Morrell, D. G.; Kochi, J. K. J. Am. Chem. Soc. 1975, 97, 7262. (e) Tamao, K.; Kiso, Y.; Sumitani, K.; Kumada, M. J. Am. Chem. Soc. 1972, 94, 4374 .

14. (a) Consiglio, G.; Morandini, F.; Piccolo, O. Tetrahedron 1983, 39, 2699. (b) Hayashi, T.; Konishi, M.; Kumada, M. Tetrahedron Lett. 1979, 21, 1871. (c) Tamao, K.; Kiso, Y.; Sumitani, K.; Kumada, M. J. Am. Chem. Soc. 1972, 94, 9268.

15. Cho, C.-H.; Kim, C.-B.; Sun, M.; Park, K. Bull. Korean Chem. Soc. 2003, 24, 1632.

16. 16. (a) Johnstone, R. A. W.; McLean, W. N. Tetrahedron Lett. 1988, 29, 5553. (b) Hayashi, T.; Katsuro, Y.; Kumada, M. Tetrahedron Lett. 1980, 21, 3915. (c) Wenkert, E.; Michelotti, E. L.; Swindell, C. S. J. Am. Chem. Soc. 1979, 2246.

17. Rudie, A. W.; Lichtenberg, D. W.; Katcher, M. L.; Davison, A. Inorg. Chem. 1978, 17, 2859.

18. Blakey, S. B.; MacMillan, D. W. C. J. Am. Chem. Soc. 2003, 125, 6046.

19. Barder, T. E.; Buchwald, S. L. Org. Lett. 2004, 6, 2649.

20. Gomes, P.; Fillon, H.; Gosmini, C.; Labbé, E.; Périchon, J. Tetrahedron 2002, 58, 8417. 